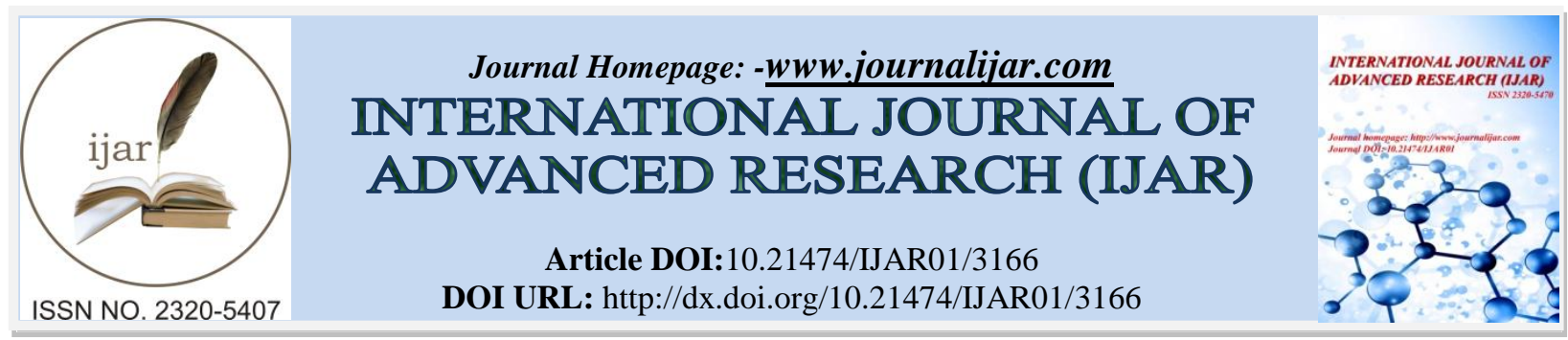

RESEARCH ARTICLE

\title{
COMPARATIVE POTENTIAL EFFICACY OF DELTAMETHRIN (PYRETHROID) AND CARBOFURAN (CARBAMATE) ON TOXICITY AND BIOCHEMICAL PARAMETERS IN THE GONADS OF CHROTOGONUS TRACHYPTERUS BLANCHARD (ORTHOPTERA: ACRIDIDAE)
}

Dr. Neetu Jangir and Dr. Saroj Bakshi.

Eco- Toxicology Laboratory, Entomology section, Center for advanced studies, Department of Zoology, University of Rajasthan, Jaipur-302055, India.

\section{Manuscript Info}

\section{Manuscript History}

Received: 18 December 2016

Final Accepted: 11 January 2017

Published: February 2017

Key words:-

Alkaline phosphatase, ATPase,

Carbofuran, Cholesterol,

Chrotogonustrachypterus , Deltamethrin,

Hypoproteinemia, Protein, Toxicity

\begin{abstract}
Potential toxicity and effect on biochemical parameters of Deltamethrin and Carboburan on gonads of Chrotogonustrachypterus was investigated. $\mathrm{LC}_{50}$ values ( $24 \mathrm{hrs}$.) for Deltamethrin $22.069 \mathrm{ppm}, 2.498$ $\mathrm{ppm}$ and forCarbofuran $14.263 \mathrm{ppm}, 1.711 \mathrm{ppm}$ on female and male Chrotogonustrachypterus respectively. Toxicity of two insecticides were not similar for both sexes but male having higher degree of toxicity than female adult at $24 \mathrm{hrs}$ of $\mathrm{LC}_{50}$ values. The effects of sublethal doses of Deltamethrin 11.034 ppm, 7.131 ppm; Carbofuran 1.249 ppm, $0.855 \mathrm{ppm}$ on gonads of adult female and male Chrotogonustrachypterus were analysed respectively. Investigation of results evaluates the Carbofuran having greater potential toxicity than Deltamethrin. Analysis of biochemical parameters as protein, cholesterol, alkaline phosphatase and ATPase were evaluated at 12, 24 and 48 hrstreatment. Hyperproteinemia $(\mathrm{p}<0.001)$ exhibited at 12, 24 and $48 \mathrm{hrs}$ after application ofDeltamethrin and Carbofuran in both sexes. The acute toxicity of pyrethroid and carbamate were compared by static exposure on Chrotogonustrachypterus. Analysis of $\mathrm{LC}_{50}$ value, evaluate that synthetic pyrethroids are less toxic than carbamates. Synthetic pyrethroid and carbamate insecticides have been developed for major uses to control crop pest in agriculture and public health.
\end{abstract}

\section{Introduction:-}

Agriculture relies heavily on the use of pesticides control of insects and other pests. Synthetic pyrethroidandcarbamateinsecticides constitute the most important class of present day pesticides which control of a pest species by affecting its unique biochemical system. The surface grasshopper, Chrotogonustrachypterus (Blanchard) (Orthoptera- Acrididae) is a destructive pest of wheat, barley, oil seed crops, maize, jowar, sunhemp, bajra, rice, sorghum, groundnut, pearl millet, cotton, vegetables, indigo, opium, red gram in different parts of the World. Deltamethrin and Carbofuran cause differential fluctuations in biochemical constituents (protein, cholesterol, ATPase and alkaline phosphatase) on gonads of Chrotogonustrachypterus which leads to sterility. $\mathrm{LC}_{50}$ values of Monocrotophos 36SL and Cypermethrin 25 EC on both the sexes of Chrotogonustrachypterus were 353.9 ppm, $151.0 \mathrm{ppm}$ and $33.11 \mathrm{ppm}, 16.38 \mathrm{ppm}$ respectively (Shakeet and Bakshi, 2009). Histopathological studies of 
Cypermethrin and Monocrotophos on expose to sublethal doses (16.56 ppm, $8.34 \mathrm{ppm}$ and $176.95 \mathrm{ppm}, 75.5 \mathrm{ppm})$ at 12, 24 and $48 \mathrm{hrs}$ on both sexes of Chrotogonustrachypterus Blanchard greatly influence process of spermatogenesis and oogenesis respectively (Shakeet and Bakshi, 2009a, 2009b).

Deltamethrin belongs to the most commonly used pesticides worldwide. Pyrethroids are divided by characteristic into type I and type II. Both types of toxicity cause neurological symptoms and reduce reproductive potential. Pyrethroids are synthetic analogues of the natural pyrethrins, extracts of the ornamental Chrysantemumcinerariaefoliumand its related species. Deltamethrin [(s) $\alpha$-cyano-3phenoxy benzy1-(R)-cis-3-(2, 2dibromoviny1)-2-2-dimethy1-cyclopropane carboxylate] a synthetic pyrethroid type İ. It is highly effective against a broad spectrum of insects with potent insecticidal properties (Manna et al., 2006). Pyrethroid caused alterations in biochemistry, hematology and reproduction (Yousefet al., 2006, El-Demerdesh, 2004) and that kills insects oncontact and through digestion. Synthetic pyrethroids are less persistent and less toxic to mammals and birds (Sayeedet al., 2003), they are highly toxic to a number of non-target organisms such as bees, freshwater fish and insects even at very low concentrations (Oudouet al., 2004), for this reason, these are extremely used in agriculture and foresty. $\mathrm{LC}_{50}$ ofDeltamethrin on female and male adults of Chrotogonustrachypterus were $22.069 \mathrm{ppm}$ and 14.263 ppm respectively. Earlier observation on Fenvalerate and Chlorpyrifos toxicity onChrotogonustrachypterus were $105.1 \mathrm{ppm}, 85.52 \mathrm{ppm}$ and $606.1 \mathrm{ppm}, 349.9 \mathrm{ppm}$ respectively (Jangir and Bakshi, 2011).

Carbofuran (2,3-dihydro-2,2-dimethylbenzofuran- 7-yl methylcarbamate) or Furadan is an anticholinesterase carbamate commonly used as an insecticide, nematicide and acaricide in agricultural practice throughout the world. Carbofuran is highly toxic by inhalation and ingestion and moderately toxic by dermal absorption. As with other carbamate compounds, carbofuran's cholinesterase-inhibiting effect isshort-term and reversible. Carbofuran has a potential to cause damage to the reproductive system and to health by prolong exposure (Nasir Aziz, 2008). $\mathrm{LC}_{50}$ of Carbofuran on female and male adults of Chrotogonustrachypterus were $2.498 \mathrm{ppm}$ and $1.711 \mathrm{ppm}$ respectively. Carbofuran has decreased the contents of carbohydrates and total protein in testicular tissue (Wael M. Al- Amound, 2012). The aim to conduct the present studywas to determine the potential toxicity and biochemical alteration in gonads of Chrotogonustrachypterusafter exposure of insecticides: Deltamethrin, Carbofuran, Cypermethrin, Fenvalerate, Chlorpyrifos and Monocrotophos.

\section{Material and Methods:-}

\section{Insecticides:-}

Carbofuran and Deltamethrin will be selected for study these were purchased from RathoreBeezBhandar,SabziMandi, LalKothi, Jaipur, India.

\section{Rearing of Chrotogonustrachypterus:-}

Chrotogonustrachypterus were collected from the fields(RajasthanUniversity ground), low crop ground, bare soil and grass or the waste land. The collected insects were conditioned in the laboratory. Rearing was done at room temperature ranging from 27 to $37^{\circ} \mathrm{C}$ in summer months and rainy days. During winter, temperature range from 27 to $32^{\circ} \mathrm{C}$ was maintained in the cages. The rearing was carried out at room humidity 35 to 65 per cent.

\section{Mode of Application:-}

Chrotogonustrachypterus were treated by dipping method because of the smaller size and hopping behaviour of the insect. About $5 \mathrm{ml}$ solution of a sub-lethal concentration of the Deltamethrin and Carbofuran was taken in a small crucible, cleared and sterilized. A grasshopper held dorsally at the thoracic region by forceps was just dipped in the insecticide contained in the crucible.

Observations were recorded on the basis of insect's mortality at $24 \mathrm{hrs}$. The results obtained were subjected to Quantal Response Assay. The $\mathrm{LC}_{50}$ of Deltamethrin and Carbofuran against Chrotogonustrachypterus were obtained by using the following formula -

$$
\log \mathrm{LC}_{50}=\quad \log _{\mathrm{Xo}_{0}}+\frac{0.50-\mathbf{P}_{\mathbf{0}}}{\mathbf{P}_{+}-\mathbf{P}_{\mathbf{0}}} \Delta
$$

Where Xo be the highest dose that gives a reaction, Po $<0.50, \mathrm{P}_{+}>0.50$ and $\Delta=$ dose step (Ipsenet al., 1970). 


\section{Determination of Sub-lethal Dose of Deltamethrin and CarbofuranagainstChrotogonustrachypterus:-}

The $\mathrm{LC}_{50}$ values of Deltamethrin and Carbofuran against female and male $C$. trachypterus were $22.069 \mathrm{ppm}, 14.263$ ppm and $2.498 \mathrm{ppm}, 1.711 \mathrm{ppm}$ respectively. In continuation of above results the sub-lethal dose of Deltamethrin and Carbofuran on female and male adults of C. trachypterus was $11.034 \mathrm{ppm}, 7.31 \mathrm{ppm}$ and $1.24 \mathrm{ppm}, 0.855 \mathrm{ppm}$ respectively when applied by the dipping method. The effects were observed after 12, 24 and $48 \mathrm{~h}$ intervals and compared with control.

\section{Bio-chemical Estimation:-}

1. Estimation of Protein: Total protein was estimated by the Lowry et al., (1951) procedure. The absorbance was read at $640 \mathrm{~nm}$ against blank. The activity was expressed in $\mathrm{mg} / \mathrm{g}$ of the wet tissue.

2. Estimation of Cholesterol: Total cholesterol was determined by the method described by Zlatkiset al., (1953). Cholesterol has unsaturated bonds and phenanthrene ring structure. The absorbance was read at $540 \mathrm{~nm}$ against blank. The activity was expressed in $\mathrm{mg} / \mathrm{g}$ of wet tissue.

3. Estimation of Alkaline Phosphatase: Alkaline phosphatase was estimated by the method after Fiske and Subba-row (1925) for the determination of phosphate liberated with modification including the incubation procedure of Bodansky $(1932,1933)$ using alkaline buffer. The phosphatase activity is the difference between the inorganic phosphate content of the incubated and control samples and is expressed in terms of Bodansky unit corresponding to the liberation of inorganic phosphorus from the tissue in $\mathrm{mg} \mathrm{pi} / \mathrm{g} / \mathrm{h}$.

4. Estimation of Adenosine Triphosphatase(ATPase): For quantitative analysis of the activity of ATPase, the method given by Sickevitz and Potter (1953) was followed. Tissues were homogenized in sucrose. Disodium salt of ATP was used as substrate. The activity was measured in term of inorganic phosphorus liberated from the tissue as for the acid and alkaline phosphatases. The absorbance was read at $640 \mathrm{~nm}$.

\section{Statistical Analysis:-}

The results obtained were expressed as mean \pm S.E. The statistical analysis by use ofStudent's t parametric test was performed to determine significant differences. The significance levels were expressed in 'P' values as

$\mathrm{NS}=$ Non significant

$\mathrm{P}<0.05=$ Significant

$\mathrm{P}<0.01=$ More significant

$\mathrm{P}<0.001=$ highly significant

\section{Results and Discussion:-}

Toxicity Results:-

Results of the bioassay of Deltamethrin and Carbofuran tested against the female and male adults of Chrotogonustrachypteruswere summarized in table 1.

Effect of Deltamethrinon female adults: Insects mortality at 400, 800, 1100, 1200, 1300 ppm concentration were $3.57,14.29,41.18,76.47$ and $100 \%$ at 24 hrs respectively (Table 1 ). $\mathrm{LC}_{50}$ value for female adults at 24 hrswas found to be $22.069 \mathrm{ppm}$ with confidence limits of 24.06 and 7.81 (Table - 2, fig -1).

Effect of Deltamethrinon male adults: Insects mortality at 200, 400, 550, 600 and $750 \mathrm{ppm}$ concentration were 10, $44.44,71.43,88.46$ and $96.97 \%$ at $24 \mathrm{hrs}$ respectively (Table 1). $\mathrm{LC}_{50}$ value for male adults at $24 \mathrm{hrs}$ was found to be 14.263 ppm with $95 \%$ confidence limits of 17.16 and 11.84 (Table -2, fig -2).

Effect of Carbofuranon female adults: Insects mortality at $0.4,0.1,0.12,0.16$ and $0.2 \mathrm{ppm}$ concentration were 3.13, $8.33,23.53,66.67$ and $95 \%$ at $24 \mathrm{hrs}$ respectively (Table 1). $\mathrm{LC}_{50}$ value for female adults at $24 \mathrm{hrs}$ wasfound to be 2.498 ppm with confidence limits of 3.11 and 2.00 (Table - 2, fig -3).

Effect ofCarbofuran on male adults: Insects mortality at $0.2,0.5,0.6,0.8$ and $0.1 \mathrm{ppm}$ concentration were $3.45,9.52$, $33.33,81.25$ and $95.65 \%$ at $24 \mathrm{hrs}$ respectively (Table 1 ). $\mathrm{LC}_{50}$ value for female adults at 24 hrswasfound to be 1.711 ppm with confidence limits of 1.93 and 1.62 (Table - 2, fig -4).

\section{Effect of Deltamethrin on biochemical parameters:-}

\section{Protein}

Male: -A highly significant $(\mathrm{P}<0.001)$ increase was recorded in protein level of male insects after 12,24 and $48 \mathrm{hrs}$ of treatment (Table 3, Fig. 5). 
Female: - Protein level highly significant increase $(\mathrm{P}<0.001)$ at 12, 24 and 48 hrsin females (Table 3, Fig. 5).

\section{Cholesterol}

Male: - There was a highly significant $(\mathrm{P}<0.001)$ increase in cholesterol level at 12 and $48 \mathrm{hrs}$ of the treatment which was followed by highly significant $(\mathrm{P}<0.001)$ decrease at $24 \mathrm{hrs}$ (Table 3, Fig 6).

Female: - Highly Significant $(\mathrm{P}<0.001)$ decrease was recorded at $24 \mathrm{hrsin}$ cholesterol levelwhile at 12 and 24 hrshighly significant $(\mathrm{P}<0.001)$ raised (Table 3, Fig. 6).

\section{Alkaline Phosphatase}

Male: - A significant decrease in alkaline phosphatase activity was recorded $48 \mathrm{hrs}$ after treatment, but slightly significant increase $(\mathrm{P}<0.01)$ after 24 hrsand highly significant $(\mathrm{P}<0.001)$ increase 12 hrsofthetreatment (Table 3, Fig. 7).

Female: - A non-significant increase in alkaline phosphatase level at $24 \mathrm{hrs}$ while at 12 and $48 \mathrm{hrs}$ significantly declined (Table 3, Fig. 7).

\section{ATPase}

Male: - ATPase level highly significant $(\mathrm{P}<0.001)$ increased 12, 24 and 48 hrs. (Table 3, Fig. 8)

Female: - ATPase analysis of result in females recorded similar as in males but at 24 hrsslightly fluctuation was occurred (Table 3, Fig. 8).

\section{Effect of Carbofuran on biochemical parameters:- \\ 1. Protein}

Male: - A highly significantly increase $(\mathrm{P}<0.001)$ in protein level was recorded at 12,24 and 48 hrs $($ Table -4 , fig-9).

Female: - There was a highly significant $(\mathrm{P}<0.001)$ increase was recorded in treated females at $12,24,48 \mathrm{hrs} \mathrm{similar}$ as in males(Table-4, fig-9).

\section{Cholesterol}

Male: - Increase in cholesterol level was highly significant $(\mathrm{P}<0.001)$ at 12 and 48 hrsof the treatment and slightly decrease at $24 \mathrm{hrs}$ in cholesterol level (Table-4, fig- 10).

Female: -Continuously highly significant $(\mathrm{P}<0.001)$ increase in cholesterol level at 12, 24 and 48 hrs were recorded (Table-4, fig-10).

\section{Alkaline phosphatase}

Male: - A highly significant $(\mathrm{P}<0.001)$ increase in alkaline phosphatase was recorded at $24 \mathrm{hrs}$ of the treatment. Thereafter a highly significant $(\mathrm{P}<0.001)$ decrease in the activity of alkaline phosphatase was recorded at 12 and 48 hrs after the treatment (Table-4, fig-11).

Female: - There was a highly significant $(\mathrm{P}<0.001)$ increase in the activity of alkaline phosphatase at 24 hrsand decrease the level of alkaline phosphatase on 12 and $48 \mathrm{hrs}($ Table-4, fig-11).

\section{ATPase}

Male: - A continuous increase of ATPase level which was highly significant $(\mathrm{P}<0.001)$ at 12,24 and 48 hrsafterthe treatment (Table-4, fig-12).

Female: - Experimental result analysis similar as in males (Table-4, fig-12).

Treatment with Deltamethrin and Carbofuran were found potentially effective, quantitative estimation of biochemical parameters viz. Protein, Cholesterol, Alkaline phosphatase and ATPase in the gonads of Chrotogonustrachypterus. 
Table1:-Effect of various concentrations of Deltamethrin and Carbofuran on female and male adults of Chrotogonustrachypterusat $24 \mathrm{hrs}$

\begin{tabular}{|c|c|c|c|c|c|c|c|c|c|}
\hline Treated Insecticides & Sex & $\begin{array}{c}\text { No. of } \\
\text { Insects }\end{array}$ & $\begin{array}{l}\text { Dose } \\
(\text { ppm) }\end{array}$ & Dead & Survived & $\begin{array}{c}\text { Survived at } \\
\text { this \& greater } \\
\text { dose } \mathrm{Sg}\end{array}$ & $\begin{array}{c}\text { Died at } \\
\text { this \& } \\
\text { Smaller } \\
\text { Dose Ds }\end{array}$ & $\begin{array}{c}\text { Sg } \\
+ \\
\text { Ds }\end{array}$ & Percentage \\
\hline \multirow{10}{*}{$\begin{array}{l}\text { Deltamethrim } \\
\text { (Pyrethroid) }\end{array}$} & $\mathrm{F}$ & 10 & 400 & 1 & 9 & 27 & 1 & 28 & 3.57 \\
\hline & $\mathrm{F}$ & 10 & 800 & 2 & 8 & 18 & 3 & 21 & 14.29 \\
\hline & $\mathrm{F}$ & 10 & 1100 & 4 & 6 & 10 & 7 & 17 & 41.18 \\
\hline & $\mathrm{F}$ & 10 & 1200 & 6 & 4 & 4 & 13 & 17 & 76.47 \\
\hline & $\mathrm{F}$ & 10 & 1300 & 10 & 0 & 0 & 23 & 23 & 100.00 \\
\hline & $\mathrm{M}$ & 10 & 200 & 2 & 8 & 18 & 2 & 20 & 10.00 \\
\hline & $\mathrm{M}$ & 10 & 400 & 6 & 4 & 10 & 8 & 18 & 44.44 \\
\hline & $\mathrm{M}$ & 10 & 550 & 7 & 3 & 6 & 15 & 21 & 71.43 \\
\hline & $\mathrm{M}$ & 10 & 600 & 8 & 2 & 3 & 23 & 26 & 88.46 \\
\hline & $\mathrm{M}$ & 10 & 750 & 9 & 1 & 1 & 32 & 33 & 96.97 \\
\hline \multirow[t]{10}{*}{ Cabofuran } & $\mathrm{F}$ & 10 & 0.4 & 1 & 9 & 31 & 1 & 32 & 3.13 \\
\hline & $\mathrm{F}$ & 10 & 0.1 & 1 & 9 & 22 & 2 & 24 & 8.33 \\
\hline & $\mathrm{F}$ & 10 & 0.12 & 2 & 8 & 13 & 4 & 17 & 23.53 \\
\hline & $\mathrm{F}$ & 10 & 0.16 & 6 & 4 & 5 & 10 & 15 & 66.67 \\
\hline & $\mathrm{F}$ & 10 & 0.2 & 9 & 1 & 1 & 19 & 20 & 95.00 \\
\hline & $\mathrm{M}$ & 10 & 0.2 & 1 & 9 & 28 & 1 & 29 & 3.45 \\
\hline & $M$ & 10 & 0.5 & 1 & 9 & 19 & 2 & 21 & 9.52 \\
\hline & $\mathrm{M}$ & 10 & 0.6 & 3 & 7 & 10 & 5 & 15 & 33.33 \\
\hline & $\mathrm{M}$ & 10 & 0.8 & 8 & 2 & 3 & 13 & 16 & 81.25 \\
\hline & $\mathrm{M}$ & 10 & 0.1 & 9 & 1 & 1 & 22 & 23 & 95.65 \\
\hline
\end{tabular}

Table 2:- $\mathrm{LC}_{50}$ values of Carbofuran and Deltamethrin for both sexes of Chrotogonustrachypterus at $24 \mathrm{hrs}$

\begin{tabular}{|l|c|c|c|c|}
\hline \multicolumn{1}{|c|}{ Treated Insecticide } & \multirow{2}{*}{ Sex } & \multirow{2}{*}{ LC $_{\mathbf{5 0}}$} & \multicolumn{2}{c|}{ 95 \% Confidence limit } \\
\cline { 3 - 5 } & & & Upper Limit & Lower limit \\
\hline Carbofuran & Female & 2.498 & 3.112 & 2.004 \\
\cline { 2 - 5 } & Male & 1.711 & 1.932 & 1.623 \\
\hline \multirow{2}{*}{ Deltamethrin } & Female & 22.06 & 24.06 & 7.81 \\
\cline { 2 - 5 } & Male & 14.26 & 17.16 & 11.84 \\
\hline
\end{tabular}

Table 3:- Biochemical alterations of Deltmethrin on gonads of Chrotogonustrachypterus (Blanchard) in control and treated groups.

\begin{tabular}{|c|c|c|c|c|c|}
\hline \multirow[t]{2}{*}{ Parameter } & \multirow[t]{2}{*}{ Sex } & \multirow[t]{2}{*}{ Group } & \multicolumn{3}{|c|}{ Time in hrs. after treatment } \\
\hline & & & 12 & 24 & 48 \\
\hline \multirow{4}{*}{$\begin{array}{l}\text { Protien } \\
\text { (mg./g.) }\end{array}$} & \multirow[t]{2}{*}{ Male } & Control & $61.13 \pm 0.5189$ & $58.46 \pm 0.7261$ & $62.1 \pm 1.5977$ \\
\hline & & Treated & $74.44 \pm 0.6739 * * *$ & $81.88 \pm 0.9165 * * *$ & $100.15 \pm 0.4739 * * *$ \\
\hline & \multirow[t]{2}{*}{ Female } & Control & $43.53 \pm 1.1951$ & $54.22 \pm 0.4453$ & $61.3 \pm 0.5258$ \\
\hline & & Treated & $53.34 \pm 0.6478 * *$ & $64.48 \pm 1.8014 * *$ & $76.64 \pm 0.2577 * * *$ \\
\hline \multirow{4}{*}{$\begin{array}{l}\text { Cholesterol } \\
\text { (mg./g.) }\end{array}$} & \multirow[t]{2}{*}{ Male } & Control & $10.47 \pm 0.2738$ & $10.2 \pm 0.4618$ & $11.36 \pm 0.1677$ \\
\hline & & Treated & $21.06 \pm 0.085 * * *$ & $18.18 \pm 0.0272 * * *$ & $25.7 \pm 0.3381 * * *$ \\
\hline & \multirow[t]{2}{*}{ Female } & Control & $8.34 \pm 0.1963$ & $9.36 \pm 0.1853$ & $9.03 \pm 0.0957$ \\
\hline & & Treated & $19.64 \pm 0.1399 * * *$ & $17.3 \pm 0.2477 * * *$ & $23.41 \pm 0.0969 * * *$ \\
\hline \multirow{4}{*}{$\begin{array}{l}\text { Alkaline Phosphatase } \\
\text { (mgpi/gm./hrs.) }\end{array}$} & \multirow[t]{2}{*}{ Male } & Control & $4.23 \pm 0.055$ & $4.16 \pm 0.0408$ & $3.08 \pm 0.0386$ \\
\hline & & Treated & $2.16 \pm 0.0708 * * *$ & $2.94 \pm 0.1905^{* *}$ & $1.74 \pm 0.3139 *$ \\
\hline & \multirow[t]{2}{*}{ Female } & Control & $3.79 \pm 0.2046$ & $3.01 \pm 0.1603$ & $3.2 \pm 0.0944$ \\
\hline & & Treated & $1.58 \pm 0.1905^{* *}$ & $3.02 \pm 0.4289 \mathrm{NS}$ & $0.38 \pm 0.2578 * * *$ \\
\hline \multirow{4}{*}{$\begin{array}{c}\text { ATPase } \\
\text { (mgpi/gm./hrs.) }\end{array}$} & \multirow[t]{2}{*}{ Male } & Control & $41.85 \pm 0.7159$ & $41.41 \pm 0.245$ & $42.16 \pm 0.0196$ \\
\hline & & Treated & $72.1 \pm 0.4903 * * *$ & $121.46 \pm 0.5195 * * *$ & $147.08 \pm 0.072 * * *$ \\
\hline & \multirow[t]{2}{*}{ Female } & Control & $42.17 \pm 0.4769$ & $45.62 \pm 0.2851$ & $46.4 \pm 0.5076$ \\
\hline & & Treated & $81.96 \pm 0.417 * * *$ & $81.47 \pm 0.6351 * * *$ & $151.51 \pm 0.2944 * * *$ \\
\hline \multicolumn{6}{|c|}{$\begin{array}{l}\text { Each value represent }- \text { Mean } \pm \text { S.E. Significance level }- \text { Control vs. Treated NS }=\text { Non significant } \\
* \mathrm{P}<0.05=\text { Significant } * * \mathrm{P}<0.01=\text { More significant } * * * \mathrm{P}<0.001=\text { Highly significant }\end{array}$} \\
\hline
\end{tabular}


Table 4:- Biochemical alterations of Carbofuran on gonads of Chrotogonustrachypterus (Blanchard) in control and treated groups.

\begin{tabular}{|c|c|c|c|c|c|}
\hline \multirow[t]{2}{*}{ Parameter } & \multirow[t]{2}{*}{ Sex } & \multirow[t]{2}{*}{ Group } & \multicolumn{3}{|c|}{ Time in hrs. after treatment } \\
\hline & & & 12 & 24 & 48 \\
\hline \multirow{4}{*}{$\begin{array}{l}\text { Protien } \\
\text { (mg./g.) }\end{array}$} & \multirow[t]{2}{*}{ Male } & Control & $50.24 \pm 0.5037$ & $50.18 \pm 0.0287$ & $51.34 \pm 0.2694$ \\
\hline & & Treated & $58.56 \pm 0.2234 * * *$ & $62.56 \pm 0.6608 * * *$ & $68.4 \pm 0.3103^{* * *}$ \\
\hline & \multirow[t]{2}{*}{ Female } & Control & $50.34 \pm 0.5416$ & $50.13 \pm 0.0558$ & $52.15 \pm 0.0589$ \\
\hline & & Treated & $56.16 \pm 0.0752 * * *$ & $58.12 \pm 0.0517 * * *$ & $65.24 \pm 0.0944 * * *$ \\
\hline \multirow{4}{*}{$\begin{array}{c}\text { Cholesterol } \\
\text { (mg./g.) }\end{array}$} & \multirow[t]{2}{*}{ Male } & Control & $8.81 \pm 0.0027$ & $7.84 \pm 0.1362$ & $7.64 \pm 0.113$ \\
\hline & & Treated & $17.84 \pm 0.0054 * * *$ & $16.21 \pm 0.0027 * * *$ & $17.97 \pm 0.0276^{* * *}$ \\
\hline & \multirow[t]{2}{*}{ Female } & Control & $6.88 \pm 0.026$ & $6.68 \pm 0.0876$ & $7.71 \pm 0.0844$ \\
\hline & & Treated & $16.21 \pm 0.0027 * * *$ & $17.83 \pm 0.0136^{* * *}$ & $17.55 \pm 0.0216 * * *$ \\
\hline \multirow{4}{*}{$\begin{array}{c}\text { Alkaline } \\
\text { Phosphatase } \\
\text { (mgpi/gm./hrs.) }\end{array}$} & \multirow[t]{2}{*}{ Male } & Control & $3.1 \pm 0.1292$ & $2.91 \pm 0.1016$ & $3.19 \pm 0.2975$ \\
\hline & & Treated & $0.8 \pm 0.2876^{* *}$ & $1.85 \pm 0.0857 * *$ & $1.34 \pm 0.2103^{* *}$ \\
\hline & \multirow[t]{2}{*}{ Female } & Control & $4.07 \pm 0.0798$ & $3.9 \pm 0.0566$ & $3.17 \pm 0.0196$ \\
\hline & & Treated & $1.14 \pm 0.0288^{* * *}$ & $1.52 \pm 0.0792^{* * *}$ & $1.03 \pm 0.0384^{* * * *}$ \\
\hline \multirow{4}{*}{$\begin{array}{c}\text { ATPase } \\
\text { (mgpi/gm./hrs.) }\end{array}$} & \multirow[t]{2}{*}{ Male } & Control & $27.25 \pm 0.4696$ & $29.76 \pm 0.1933$ & $29.85 \pm 0.0236$ \\
\hline & & Treated & $60.15 \pm 0.0558 * * *$ & $122.04 \pm 0.0054 * * *$ & $132.4 \pm 0.174 * * *$ \\
\hline & \multirow[t]{2}{*}{ Female } & Control & $29.97 \pm 0.0249$ & $30.41 \pm 0.162$ & $31.17 \pm 0.0249$ \\
\hline & & Treated & $59.43 \pm 0.1787 * * *$ & $120.48 \pm 0.2749 * * *$ & $140.52 \pm 0.2655^{* * *}$ \\
\hline & & & 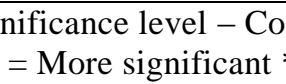 & Vs. TIEaled NS & $\begin{array}{l}\text { significant } \\
\text { ficant }\end{array}$ \\
\hline
\end{tabular}

Fig. 1:- Effect of Deltamethrin on protein level in gonads of Chrotogonustrachypterus

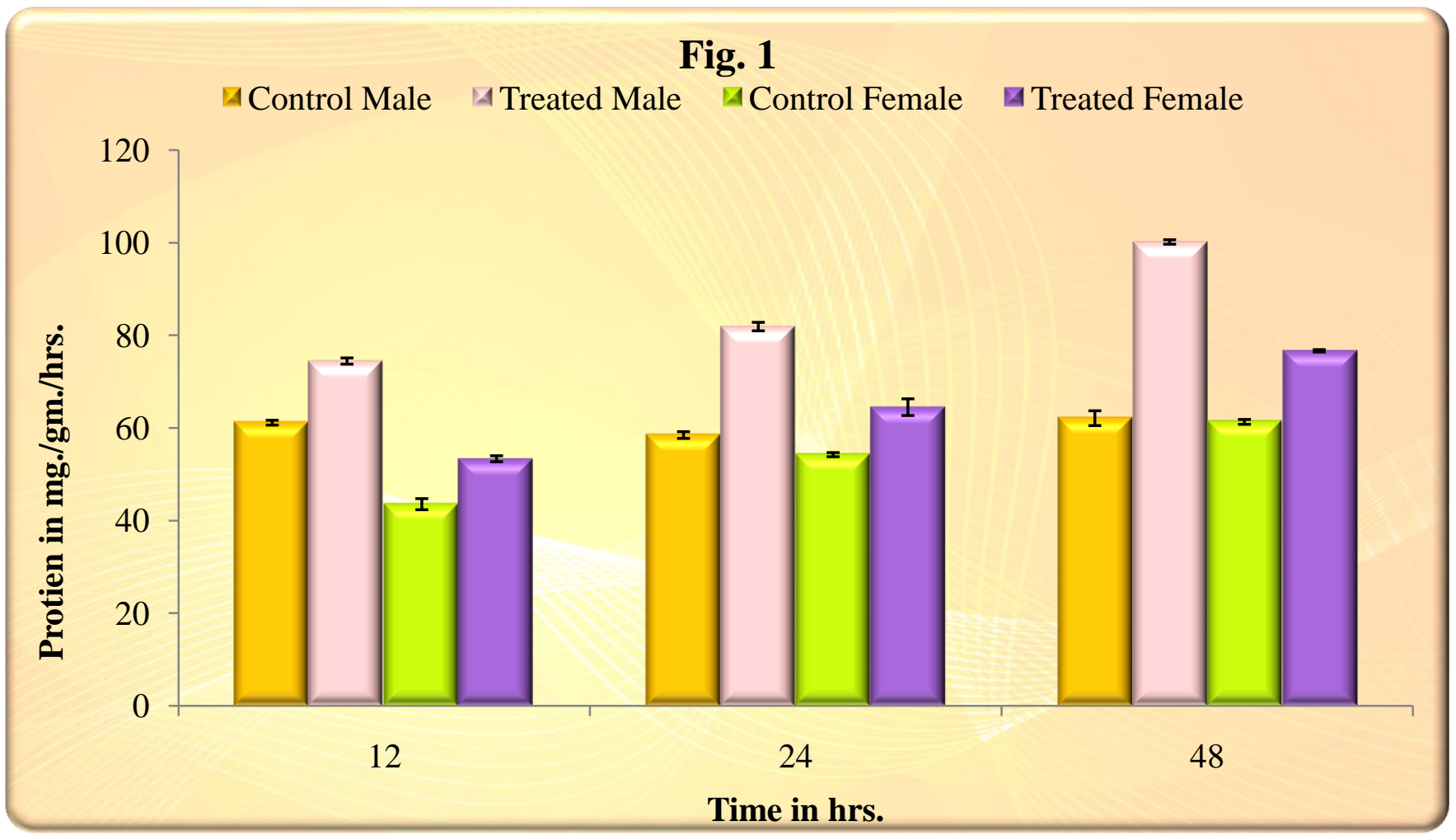


Fig. 2:-Effect of Deltamethrin on Cholesterol level in gonads of Chrotogonustrachypterus.

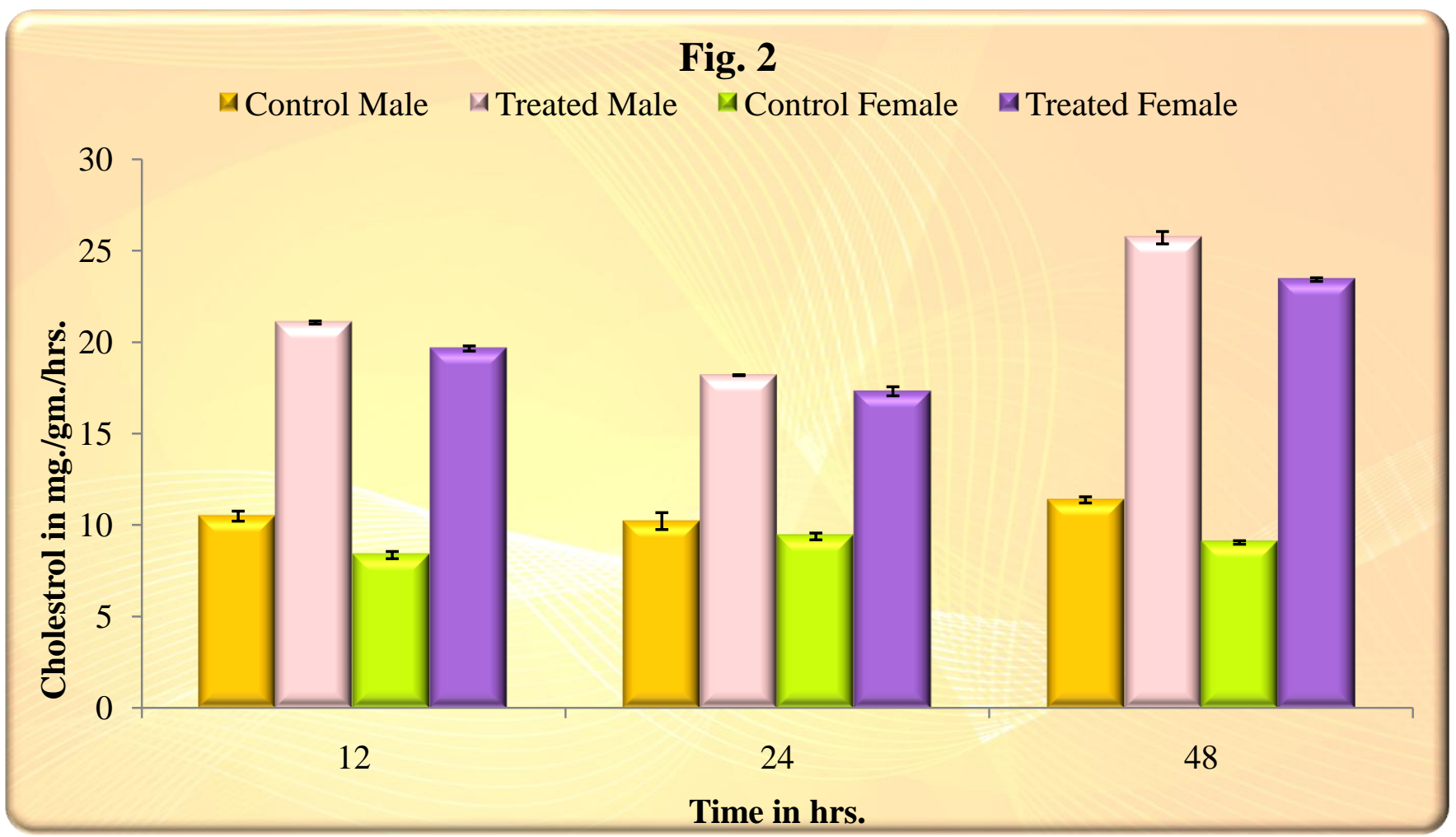

Fig. 3:-Effect of Deltamethrin on Alkaline Phosphatase level in gonads of Chrotogonustrachypterus.

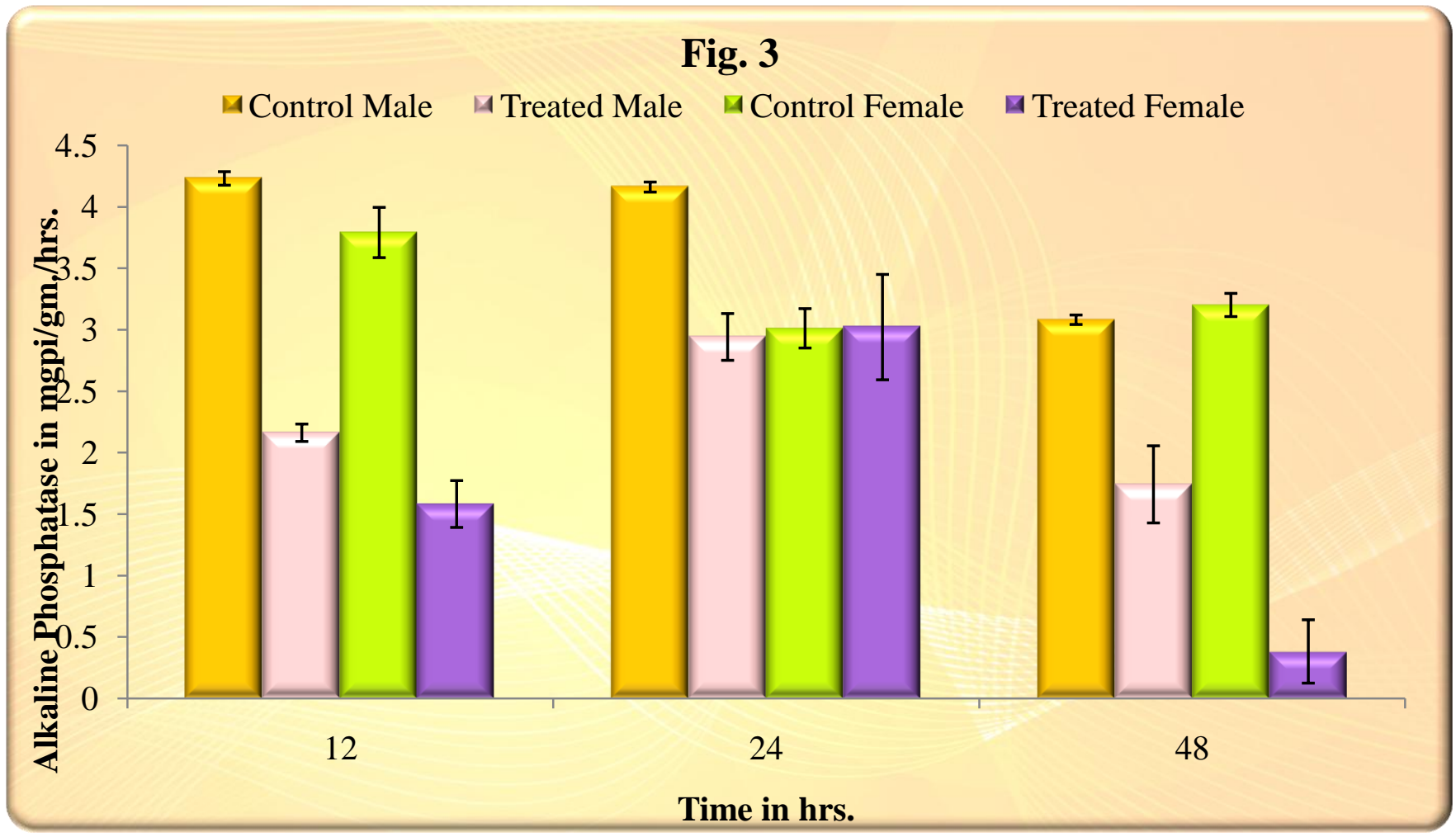


Fig. 4:-Effect of Deltamethrin on ATPase level in gonads of Chrotogonustrachypterus

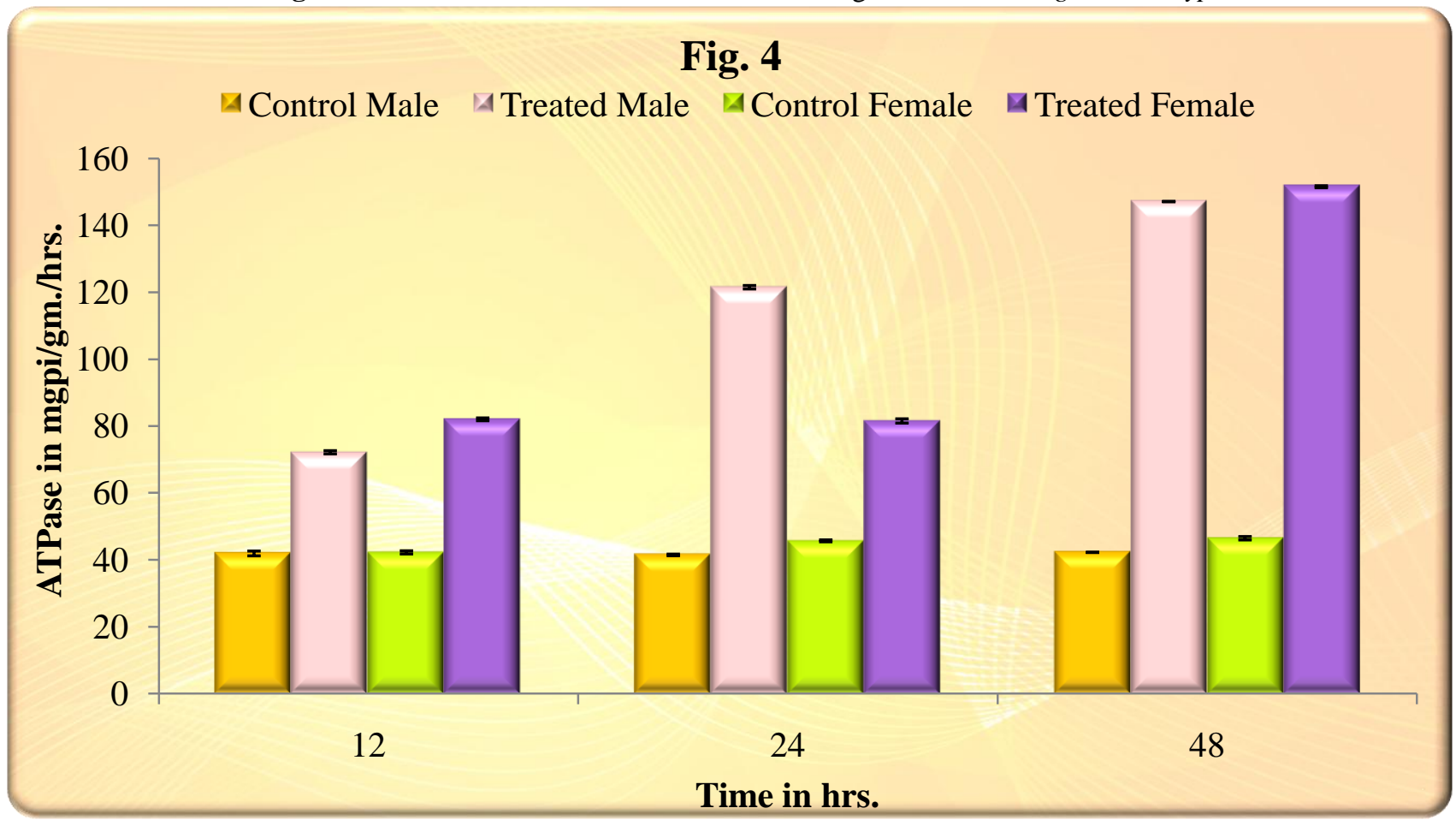

Fig. 5:-Effect of Carbofuran on protein level in gonads of Chrotogonustrachypterus

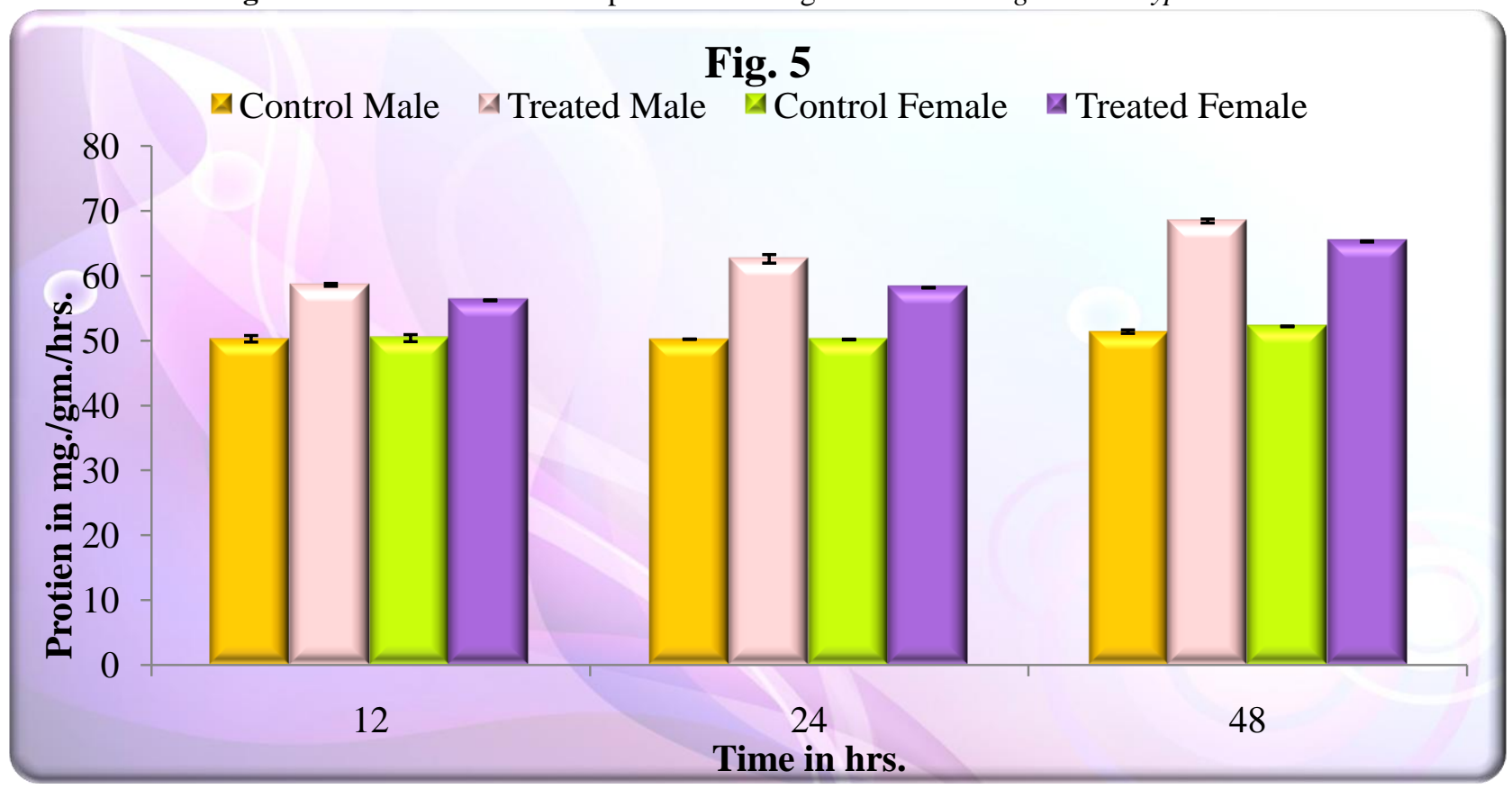


Fig. 6:- Effect of Carbofuran on Cholesterol level in gonads of Chrotogonustrachypterus.

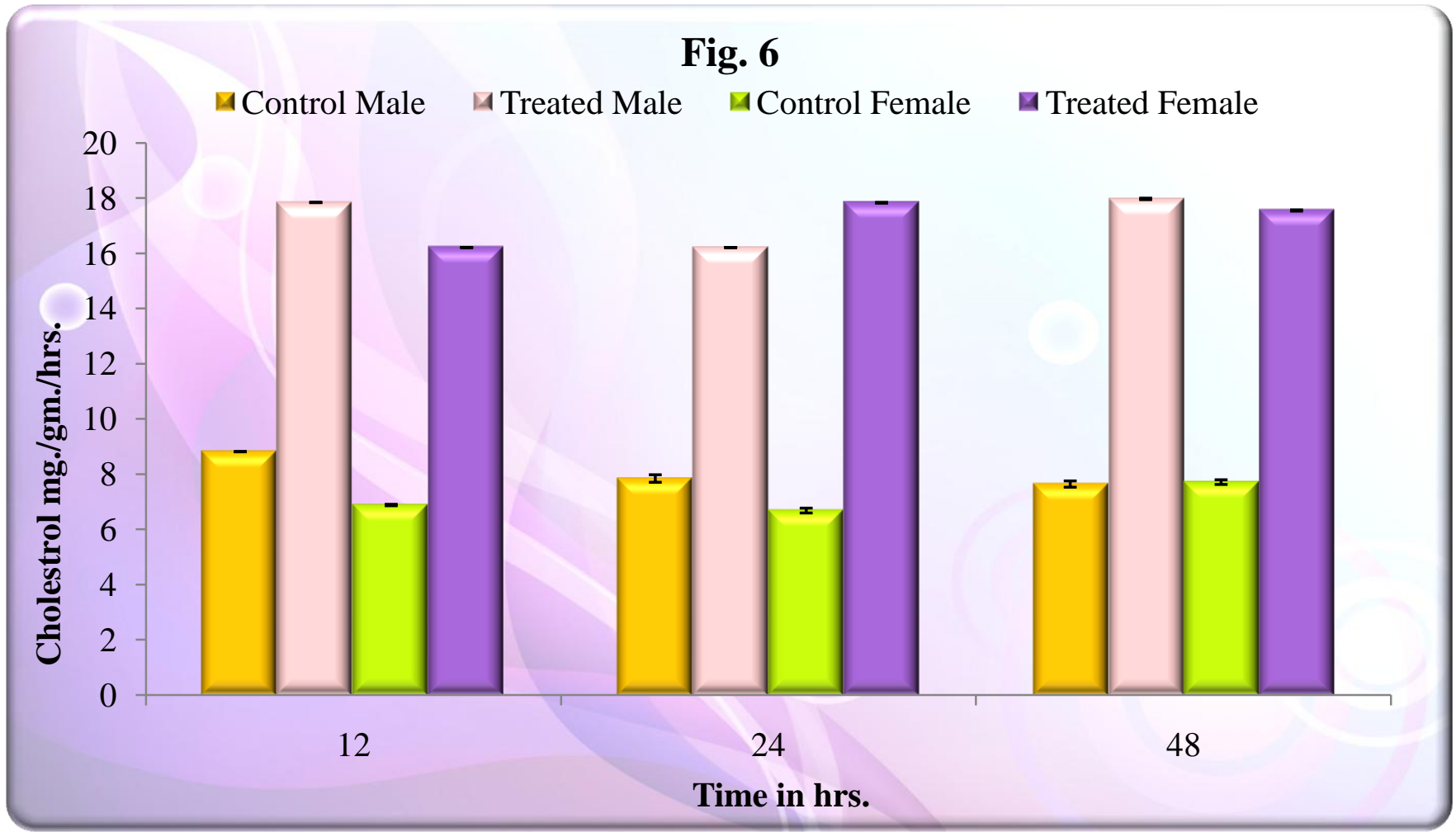

Fig. 7:-Effect of Carbofuran on Alkaline Phosphatase level in gonads of Chrotogonustrachypterus.

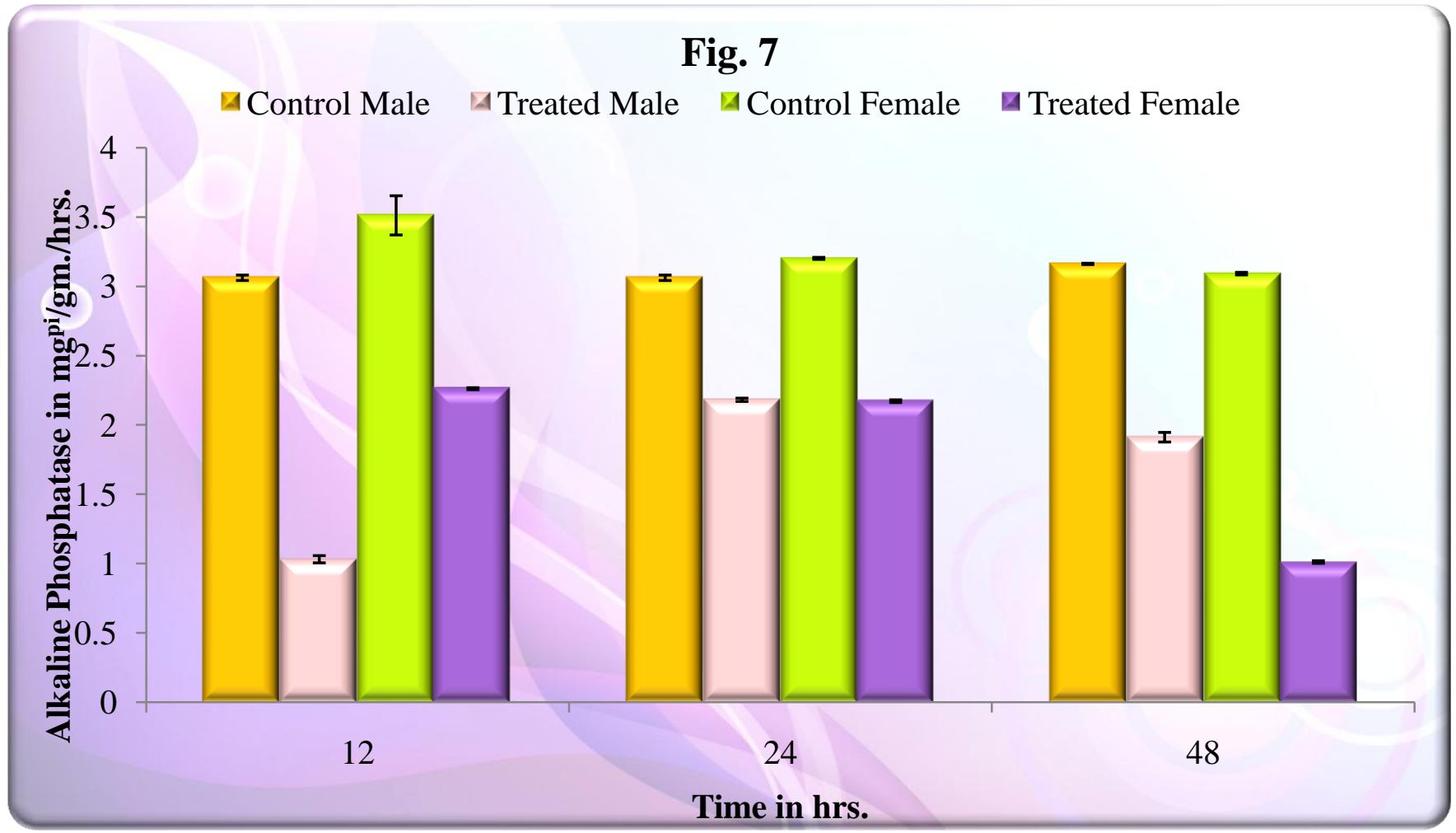


Fig. 8:-Effect of Carbofuran on ATPase level in gonads of Chrotogonustrachypterus.

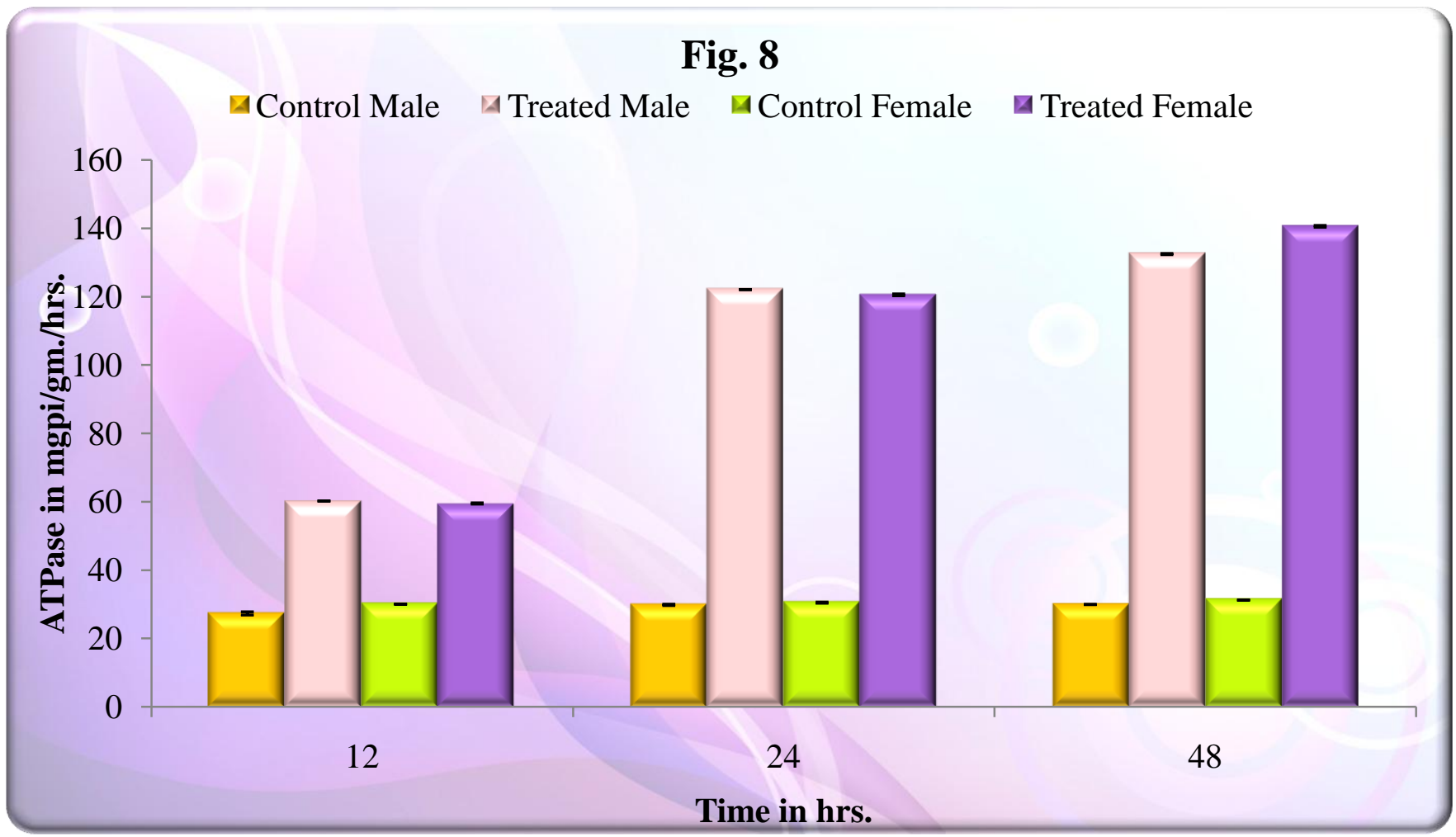

\section{Discussion:- \\ Potential Toxicology:-}

Toxicity of insecticides is highly dependent on the duration, frequency, intensity of exposure and the susceptibility of the target organism which is influenced by age, sex, fitness and genetic variation. The tested insecticides, Deltamethrin andCarbofuranexhibited a fair degree of contact toxicity on female and male adults of Chrotogonustrachypterus. $\mathrm{LC}_{50}$ values $(24 \mathrm{hrs}$.$) for Deltamethrin and Carbofuranon female and$ maleChrotogonustrachypterus were $22.069 \mathrm{ppm}, 14.263 \mathrm{ppm}$ and $2.498 \mathrm{ppm}, 1.711 \mathrm{ppm}$ respectively.Observation findings emphasis that male adults were more susceptible to compounds than female adults. Results directly reflected that more mortality of male Chrotogonustrachypterus also reduce the fertility. Earlier observations revealed that the $\mathrm{LC}_{50}$ value of Monocrotophos $36 \mathrm{SL}$ and Cypermethrin $25 \mathrm{EC}$ against female and male adults of Chrotogonustrachypterus by dipping method, were $353.9 \mathrm{ppm}, 151.0 \mathrm{ppm}$ and $33.11 \mathrm{ppm}, 16.38 \mathrm{ppm}$ respectively (Shakeet P. and Bakshi S., 2009).Jangir N. and Bakshi S. (2011) also observed that Fenvalerate (85.52 ppm) is more toxic than Chlorpyrifos (349.9 ppm). Present findings also supported byChoudharyet al. (2000), that Fenvalerate (pyrethroid) were more toxic than chlorpyrifos(phosphate) when they investigate relative toxicity of insecticides against Acrotylushumbertianus grasshopper. Toxicity on subterranean termite Coptotermesformosanus were determined on Deltamethrin(pyrithroid) $\mathrm{LD}_{50}$ was most toxic and Chlordane least toxic (Su, Nan- Yao et al., 1990). According to Blair D.Siegfrid (1993), the acute toxicity of three pyrthroids (permethrin, cypermethrin,bifenthrin) greater than one organophosphate insecticide (chlorpyrifos).RadkaDobsikova (2003), revealed that test of acute toxicity with Carbofuran confirmed the high toxicity of the chemical to selected species of aquatic organism than terrestrial organism. According to NitinSood and Sharma D C (2004), synthetic pyrethroids have higher persistent toxicity than neemderivaties. Experimental results also exhibit both the insecticides have shown to be consistent effective in controlling Chrotogonustrachypterus in field crops.The present findings derive ample support in pest management and saving the crops against damage from the pest Chrotogonustrachypterus. Conclusion of the present investigation analyse that the carbamates are more toxic than synthetic pyrethroids and organophosphates. Potential effect of toxicity on insecticides were - 
Chlorpyrifos $(349.9 \mathrm{ppm})<$ Monocrotophos $(151.0 \mathrm{ppm})<$ Fenvalerate $(85.52 \mathrm{ppm})<$ Cypermethrin $(16.38 \mathrm{ppm})$ $<$ Deltamethrin (14.26) <Carbofuran (1.71) (Table - 2)

\section{Biochemical Parameters:- \\ Protein:-}

Current study results summarize Chrotogonustrachypterus treated with sub-lethal dose of Deltamethrin and Carbofuran exhibited hyperproteinemia or increase the protein level in both sexes till $48 \mathrm{~h}$ when the experiment was terminated. Smitha and Rao (2010), evaluate sublethal dose of selenium on silk worms showed significantly increase in females at $12 \mathrm{hrsafter}$ treatment and also showing hyperproteinemia on all exposure periods. The effect of Bacillus thuringiensis var. kurstaki on biochemical alteration in haemolymph found protein content increase in experiment (Tripathi and Singh, 2002). Toxicant influence of Fenvalerate the proteins and glycogen levels totally decreased in various tissues of Channapunctatus (Bloch) (Satyavardhan, 2010). Biochemical alterations after effect of sub-lethal doses (176.95 and $75.5 \mathrm{ppm}$ ) of Monocrotophos on gonads of female and male C.trachypterus as protein, cholesterol and alkaline phosphatase decrease and ATPase level increase (Shakeet and Bakshi, 2010a). Deltamethrin induced a significant decline in serum total protein concentration, albumin and globulin at third day of first, second and fourth week after application of Deltamethrin in buffaloes (El Nabarawy., 2008). Histochemical results revealed that animals given Carbofuran had decreased contents of carbohydrates and total proteins in the testicular tissue. Treating mice with Carbofuran and vitamin $\mathrm{C}$ showed an improvement in testicular damage (Wael M. Al-Amoudi, 2012). Significantly reduced total head protein after 24, 48, and $72 \mathrm{~h}$ treated of Ageratum conyzoides L. and Artemisia vulgaris (L.) in third and fourth instar larvae of Spodopteralitura (Renuga and Sahayaroj, 2009).

\section{Cholestrol:-}

Earlier observation of Shakeet and Bakshi (2010b), effect of Cypermethrin on biochemical parameters on gonads of C.trachypterus as the protein, cholesterol, acid phosphatase and ATPase increase in level and decrease the level of alkaline phosphatase. Current results showed that cholesterol level was highly significantly $(\mathrm{p}<0.001)$ raised at 12 , 48 hrsand slightly decline at 24 hrs after exposed to Deltamethrin and Carbofuran in both sexes. The effects of sublehtal doses of Cypermethrinon the sixth instar larvae of T. castaneum (Saleemet al., 2005) the high cholesterol level on gonads of L. augur parasitized by $H$. vishwakarma. Level of cholesterol level significantly increased in mice after exposure of carbosulfan and adverse effects on liver functions leading tophysiological impairment (R.L. Ksheerasagar1, M.B. Hiremath and B.B. Kaliwal, 2011).It is expected that the changes in the cholesterol level in the tissue may contribute to the dis-functioning of hormonal balance due to disturbed metabolism and affecting reproduction.

\section{Alkaline Phosphatase;-}

A non-significant increase in alkaline phosphatase activity treated with Deltamethrin at 24 hrs was recorded in female adults and significantly declined $(\mathrm{p}<0.01)$ at 12,24 and 48 hrsin male adults. While after application of Carbofuran, highly significantly ( $\mathrm{p}<0.001)$ increase in alkaline phosphatase level at 12 and 48 hrsin male adults and slightly flucations at $24 \mathrm{hrs}$ in both sexes. Spinosad caused depletion in alkaline phophatase activity while increase in acid phosphatase activity in treated T. castaneum (Hussain, 2009). Methomyl (carbamate) induced gonadal dysfunction, biochemical contents and enzyme activities in male albino mice.Biochemical studies of testis and epididymis showed methomyl at doses of 2, 3 and $4 \mathrm{mg} / \mathrm{kg} /$ day and in $4 \mathrm{mg} / \mathrm{kg} /$ day for 10 and 20 days ofmethomyl treatment caused significant decrease in the levels of DNA, RNA, protein, glycogen and sialic acid whereas cholesterol increased significantly and alkaline phosphatase and ATPase decreased (Manawadi S.I. and Kaliwal B.B., 2010).

\section{ATPase (Adenosine Triphosphatase):-}

The activity of the energy enzyme ATPase obtained highly significant increase in both the sexes treated with Deltamethrin and Carbofuran. The finding of the present investigation reveals that enough energy is consumed during metabolism due to the effect of the Deltamethrin since an increase in the activity of ATPase. Helena Cristina Da Silva de Asiset al., (2009) found that Deltamethrin inhibited the activity of gills and heart $\mathrm{Na}^{+}-\mathrm{K}^{+}$ATPase,, induced liver total CYP 450 as well as the liver EROD activity. 


\section{References:-}

1. Blair D. Siegfried, (1993). Comparative Toxicity of pyrethroid insecticides to terrestrial and aquatic insects. Environmental Toxicolgy and Chemistry, 12: 1683-1689.

2. Choudhary U B, Sanmerwar M, Pyarelal and Sangwan M N. (2000). Relative toxicity of insecticides against AcrotylushumbertianusSauss.Plant protection Bulletin52: 4-5.

3. El Nabarawy, E. A. and Alam, T. H., (2008). Effect of Deltamethrin insecticide on some haemato-biochemical parameters in buffaloes with its effect on immunoglobulins and its residues in raw milk. Egypt. J. Comp. Path. And Clinic. Path., 21(1): 344-359.

4. Haug, G. and H. Hoffman, (1990). Chemistry of plant protection 4: Synthetic pyrethroid insecticides: Structures and properties. Springer Verlag. Berlin, Heidelberg, New York.

5. Helena Cristina da Silva de Assis, LilianNicareta, Ligia Maria Salva, et al., (2009).Biomarkers of exposure to Deltamethrin in freshwater fish, Ancistrusmultispinis. Brazilian Archives of Biology and Technology, 52(6): 14011407.

6. Hussain, R., Muhammad, A. and Saleem, M. A., (2009). Biochemical abnormalities produced by spinosad in Triboliumcastaneum adult beetles. Int. J. Agri Biol., 11(3): 241-244.

7. Jangir, N. and Bakshi, S., (2011). Comparative Toxicity of Chlorpyrifos and Fenvalerate for the control of Chrotogonustrachypterus(Orthoptera: Acrididae). Res. J. Agric. Sci., 2(4): 902-904.

8. Manawadi S.I. and Kaliwal B.B., (2010). Methomyl induced gonadal dysfunction, biochemical contents and enzyme activities in male albino mice. International Journal of Biotechnology Application, 2(2): 20-32.

9. Nasir Aziz, S. Walliullah Shah and RabailNasir Aziz, (2008). Histological changes in male rat reproductive organs post treated with insecticide Carbofuran (Furadan), Animals of Microscopy, 8: 83-89.

10. NitinSood and D C Sharma, (2004).Bioefficacy and persistent toxicity of different insecticides and Neem derivatives against Cucurbits fruit fly, Bactroceracucurbitae on summer Squash. Pesticide Research Journal, 16(2): 22-25.

11. Oudou, H. C., Alonso, R. M., Bruun Hansen, H. C. (2004).Voltammetricbehavior of the synthetic pyrethroid lambdacyhalothrin and its determination in soil and well water.Anal.Chim.Acta, 523, 69-74.

12. R.L. Ksheerasagar1, R. L., Hiremath, M.B. and Kaliwal, B. B., (2011). Impairment of hepatic biochemical contents and enzymes activities during carbosulfanintoxication in albino mice.International Multidisciplinary Research Journal, 1(3): 06-15.

13. RadkaDobsikova, (2003). Acute toxicity of Carbofuran to selected species of aquatic and terrestrial organism. Plant Protect. Sci., 39:103-108.

14. Renuga, F. B. and Sahayaroj, K., (2009). Influence of botanicals in total head protein Spodopteralitura (Fab.). J. Biopestic., 2(1): 52-55.

15. Saleem, M. A. and Shakoori, A. R., (2005).Permethrin and malathion induced macromolecular abnormalities in adult Triboliumcastaneum (Herbst). Arch. Insect. Biochem. Physiol., 5(1): 45-55.

16. Satyavardhan, K., (2010).Effect of Fenvalerate ${ }^{\mathrm{TM}}$ on various Tissues of Chanapunctatus (Bloch). World App. Sci. J., 10(1): 70-74.

17. Sayeed, I., Parvez, S., Pandey, S., Bin-Hafeez, B., Haquee, R., Raisuddin, S. (2003). Oxidative stress biomarkers of exposure to deltamethrin in freshwater fish, ChannapunctatusBloch.Ecotoxicol. Environ.Saf.,56, 295-301.

18. Shakeet, P. and Bakshi, S., (2009). Toxicity of Monocrotophos and Cypermethrin against Chrotogonustrachypterus. J. Herb. Medi.Toxico, 3(1): 149-152.

19. Shakeet, P. and Bakshi, S., (2009a). Histopathology of gonads of Chrotogonustrachypterus (Blanchard) treated with sublethal doses of Monocrotophos. Karnataka J. Agri. Sci., 22(spl. Issue): 507-510.

20. Shakeet, P. and Bakshi, S., (2009b). Histopathological effect of Cypermethrin on gonads of ChrotogonustrachypterusBlan. (Orthoptera: Acrididae). Pak. Entomol., 31(1): 17-24.

21. Shakeet, P. and Bakshi, S., (2010). Biochemical Alterations in the gonads of Chrotogonustrachypterus (Blanchard) Treated with sub-lethal Dose of Monocrotophos. J. Life. Sci., 2(2): 107-115.

22. Shakeet, P. and Bakshi, S., (2010a). Effect of Cypermethrin on biochemical parameters on gonads of Chrotogonustrachypterus (Orthoptera-Acrididae). Indian J. Agric. Res., 44(4): 242-250.

23. Smitha, S., and VijyaBhaskaraRao, A., (2010). Alterations in the HaemolymphBiochemical Parameters of Silkworm Bombyxmori L. Treated with Selenium. Am-Euras. J. Toxicol. Sci., 2(1): 51-53.

24. Su, Nan-Yao, Schelfrann and Rudolf H. (1990). Comparison of eleven soil Termiticides against the Formosan Subterranean termite (Isoptera :Rhinotermitidae). Journal of Economic Entomology 83: 1918-1924

25. Tripathi, R. and Singh, N. P., (2002).Biochemical Alterations in the Haemolymph of Bacillus thuringiensis var. kurstaki (B.t.k.) Infected Larvae of Spodopteralitura (Fab). Asian J. Exp. Sci., 16(1\&2): 35-39.

26. Wael M. Al- Amoudi, (2012). Protective effect of vitamin C against Carbofuran Induced testicular toxicity in Albino mice. Journal of American Sciences, 8(1): 335-341.

27. Yousef, M. I., Awad, T. I. and Mohamed E. H., (2006).Deltamethrin induced oxidative damage and biochemical alterations in rat and its attenuation by vitamin E. Toxicology, 227(3): 240-247. 